\title{
PEMBERDAYAAN KELOMPOK PETERNAK SAPI MELALUI BUDIDAYA RUMPUT MULATO DAN TEKNOLOGI PENGOLAHAN LIMBAH TERNAK
}

\author{
Novi Mayasari ${ }^{1}$, Indra Firmansyah ${ }^{2}$ dan Muhammad Rifqi Ismiraj ${ }^{3}$ \\ ${ }^{1}$ Departemen Nutrisi Ternak dan Industri Pakan, Fakultas Peternakan, Universitas Padjadjaran \\ ${ }^{2}$ Environmental Technology Group, Wageningen University, Belanda \\ ${ }^{3}$ Program Studi Peternakan, Fakultas Peternakan, Universitas Padjadjaran, PSDKU Pangandaran \\ E-mail: novi.mayasari@unpad.ac.id
}

\begin{abstract}
ABSTRAK. Pengadaan pakan terutama ketersediaan hijauan yang kontinuitas dan berkualitas dalam usaha peternakan merupakan input utama yang harus dipenuhi untuk hidup ternak, sehingga mampu mencapai produksi optimal. Di sisi lain, salah satu persyaratan aktivitas peternakan yang berkesinambungan perlu mempertimbangkan aspek kelestarian lingkungan, salah satunya adalah sistem penanganan limbah yang baik. Guna mencapai tujuan tersebut, dibutuhkan pengetahuan mengenai jenis hijauan yang berkualitas, serta pengenalan teknologi pengolahan limbah yang dapat diaplikasikan di peternakan. Salah satu jenis rumput yang dilaporkan berpotensi memiliki kandungan nutrient yang baik adalah rumput mulato II (Brachiaria hybrid cv. Mulato), yang dilaporkan memiliki keunggulan, seperti daya adaptasi rumput mulato pada kualitas tanah yang rendah pada musim kemarau sangat baik. Salah satu metode yang dapat dilakukan adalah mengkonversi bahan-bahan bernilai nutrient dalam limbah ternak menjadi produk gas yang dapat digunakan sebagai sumber energi, melalui fenomena fermentasi anaerob yang dilangsungkan oleh bakteri fermentatif anaerob yang dapat menghasilkan biogas. Hasil dari laporan-laporan studi tersebut dirasa perlu untuk diinformasikan kepada para peternak, dengan cara penyuluhan. Penyuluhan dilaksanakan secara daring dengan menggunakan aplikasi Zoom Meeting. Kegiatan penyuluhan daring yang berisikan materi mengenai pengenalan teknologi pengolahan limbah peternakan dan pengenalan potensi rumput mulato sebagai hijauan untuk ruminansia dapat diterima dengan baik oleh para peserta penyuluhan, ditandai dengan $90 \%$ peserta dapat menjawab pertanyaan evaluasi dari para narasumber.
\end{abstract}

Kata kunci: rumput Mulato II; limbah ternak; teknologi pengolahan; penyuluhan; daring

ABSTRACT. The supply continuity of feed and quality forage in the livestock business are the main inputs that have to be fulfilled for livestock, so that it can achieve optimal production. On the other hand, one of the requirements for sustainable livestock activities needs to consider aspects of environmental sustainability, one of which is a good waste management system. In order to achieve these goals, knowledge of quality forage types is needed, as well as the introduction of waste treatment technology that can be applied in animal husbandry. One type of grass reported to have the potential to have good nutrient content is mulato grass II (Brachiaria hybrid cv. Mulato), which is reported to have advantages, such as the adaptability to low soil quality during the dry season. One method that can be done to assure good waste management is to convert nutrient-valued materials in livestock waste into gas products that can be used as an energy source, through the anaerobic fermentation phenomenon carried out by anaerobic fermentative bacteria, to produce biogas. It is deemed necessary for the results of these study reports to be informed to farmers, by means of extension. The extension activity is carried out by online method using the Zoom Meeting application. Online extension activities containing material on the introduction of livestock waste processing technology and the introduction of the potential of mulato grass as a forage for ruminants were well received by the extension participants, marked by $90 \%$ of participants being able to answer evaluation questions from the mentors.

Keywords: Mulato II grass; Animal waste; processing technology; extension; online

\section{PENDAHULUAN}

Pengadaan pakan terutama ketersediaan hijauan yang kontinuitas dan berkualitas dalam usaha peternakan merupakan input utama yang harus dipenuhi untuk hidup ternak, sehingga mampu mencapai produksi optimal (Adawiah et al., 2006). Oleh karena itu, kuantitas maupun kualitas pakan yang diberikan harus memenuhi standar kebutuhan ternak, seperti kebutuhan hidup pokok, produksi dan lainnya (Widyobroto et al., 2016). Di sisi lain, harga pakan juga harus ekonomis, untuk menekan biaya produksi.

Secara umum, kondisi pakan terutama hijauan untuk ternak di Indonesia belum sepenuhnya mampu memenuhi kebutuhan ternak, sehingga peternak menambahkan konsentrat sebagai bahan pakan tambahan seperti ampas tahu dan bubuk kue untuk memenuhi kebutuhan ternak (Mayasari et al., 2018). Jawa Barat merupakan salah satu lokasi penghasil susu yang menjadi andalan nasional disamping Jawa Tengah dan Jawa Timur. Populasi ternak perah di Jawa Barat cukup tinggi, yaitu sekitar 120.650 ekor (Badan Pusat Statistik Republik Indonesia, 2020) sehingga banyak membutuhkan suplai pakan yang baik.

Guna mencapai tujuan tersebut, dibutuhkan pengetahuan mengenaijenis hijauan yang berkualitas. Pencarian jenis hijauan yang mampu menghasilkan biomassa yang banyak dengan kualitas yang baik dan rentan terhadap kekeringan sangat penting 
sehingga dapat memenuhi kebutuhan ternak secara efektif dan efisien, sehingga usaha peternakan dapat berkesinambungan (Mayasari \& Ismiraj, 2019). Salah satu jenis rumput yang dilaporkan berpotensi memiliki kandungan nutrien yang baik adalah rumput mulato II (Brachiaria hybrid cv. Mulato), yang dilaporkan memiliki keunggulan, seperti daya adaptasi rumput mulato pada kualitas tanah yang rendah pada musim kemarau sangat baik (Inyang et al., 2010), pertumbuhannya kembali yang cepat setelah digembalakan atau dipotong, kualitas gizinya sangat baik (kandungan protein kasar yang cukup tinggi 12-20\%; Argel dkk., 2007) dan memiliki anakan yang cukup banyak. Mulato memiliki tingkat palabilitas yang baik dan biomassa yang tinggi, sehingga budidaya rumput mulato ini lebih cepat diterapkan pada peternak rakyat (Maass et al., 2015).

Di sisi lain, salah satu persyaratan aktivitas peternakan yang berkesinambungan perlu mempertimbangkan teknologi yang ramah lingkungan, salah satunya adalah sistem penanganan limbah yang baik (Kaufmann, 2015; Sorathiya et al., 2014). Aspek isu lingkungan menjadi isu hangat bagi masyarakat dunia, dikarenakan adanya indikasi dampak lingkungan, seperti perubahan iklim global akibat efek gas rumah kaca yang salah satunya disebabkan oleh aktivitas produksi ternak (Koneswaran \& Nierenberg, 2008). Limbah ternak merupakan bahan yang sejatinya masih dapat dilakukan pemrosesan untuk dikonversi menjadi manfaat yang lain sebelum dibuang ke lingkungan (Budde et al., 2016). Limbah ternak mengandung cukup banyak jerami, yang hampir tidak bisa dicerna di bawah kondisi pencernaan anaerobik biasa (Grabber, 2005), yang oleh karenanya dapat dilakukan pemrosesan bahanbahan yang masih bermanfaat dalam limbah ternak. Salah satu metode yang dapat dilakukan adalah mengkonversi bahan-bahan bernilai nutrient dalam limbah ternak tersebut menjadi produk gas yang dapat digunakan sebagai sumber energi, melalui fenomena fermentasi anaerob yang dilangsungkan oleh bakteri fermentatif anaerob. Proses konversi dengan fermentasi anaerob ini dapat menghasilkan biogas.

Hasil dari laporan-laporan studi tersebut dirasa perlu untuk diinformasikan kepada para peternak dengan harapan meningkatkan keberdayaannya dalam praktik produksi ternak, serta untuk memberikan inspirasi untuk melaksanakan aktivitas beternak yang lebih ramah lingkungan. Namun, terjadi pandemi Covid-19 di tahun ini, sedikit banyak membatasi mobilitas kami sebagai peneliti maupun peternak. Oleh karenanya, kegiatan pengabdian kepada masyarakat ini dilaksanakan secara daring kepada beberapa kelompok peternak yang kami ketahui, yang berlokasi di Kabupaten Sumedang,
Kabupaten Pangandaran, Kabupaten Sukabumi, Kabupaten Garut, dan Kabupaten Pekanbaru.

\section{METODE}

Kegiatan PKM dilaksanakan pada bulan Januari - Februari 2021. Kondisi pandemi Covid-19 merubah kebiasaan dari bentuk pengabdian yang umunya dilakukan secara luring menjadi daring, atau dilakukan secara virtual. Inti dari kegiatan ini adalah kegiatan penyuluhan secara daring (virtual) dengan menggunakan aplikasi Zoom Meeting kepada para perwakilan peternak di beberapa lokasi di Indonesia. Namun, sebelum kegiatan penyuluhan tersebut dilaksanakan, terlebih dahulu dilakukan persiapan, sehingga seluruh rangkaian kegiatan ini terbagi ke dalam beberapa tahap, yakni: a. tahap persiapan; $b$. tahap pelaksanaan penyuluhan daring; dan c. tahap evaluasi dan pendampingan.

Tahap persiapan diawali dengan koordinasi antara tim pelaksana pengabdian kepada masyarakat (PKM) terdiri atas dosen dan mahasiswa yang sedang melaksanakan kegiatan kuliah kerja nyata $(\mathrm{KKN})$. Koordinasi internal tim ini bertujuan untuk menentukan mitra, pembagian tugas dan membuat kuesioner sebagai bahan wawancara. Perkenalan dengan mitra dan penjajagan dilakukan sesuai dengan pembagian tugas. Penjajagan dilakukan secara virtual melalui Whatsapp dan juga secara daring dengan protokol kesehatan yang sangat ketat. Program pengabdian yang dilakukan dilakukan pada berbagai wilayah dimana mahasiswa berada seperti di Sumedang, Sukabumi, Riau dan Pangandaran. Tim pelaksana PKM telah memiliki mitra khusus yaitu kelompok peternakan di KSU Tandangsari dan Kelompok Peternak Putra Nusa telah secara reguler per tahun, dari tahun 2018. Hal ini memudahkan mahasiswa mendapatkan mitra dan melakukan proses penjajagan. Penjajakan untuk mitra baru di Sukabumi, Garut dan Riau dilakukan dengan cara pendekatan persuasif terhadap peternak.

Penjajakan dan wawancara dilakukan dan dimaksudkan untuk mengetahui update dan mengidentifikasi kondisi di lapangan. Berdasarkan penjajakan tersebut, maka diperoleh informasi bahwa peternak, memiliki masalah dalam pengadaan hijauan pakan, masalah sumber pakan, masalah kesehatan dan masalah terkait pengolahan limbah peternakan. Berdasarkan permasalahan yang diperoleh saat tahap penjajakan tersebut, dirumuskanlah solusi yang ditawarkan, yaitu penyuluhan secara daring dengan topik "Pemberdayaan Kelompok Peternak Sapi melalui Introduksi Teknologi Pengolahan Limbah Peternakan dan Rumput Mulato sebagai Sumber Hijauan Ruminansia". Selain itu, pada tahap persiapan ini juga dilaksanakan berbagai persiapan 
acara penyuluhan secara daring, meliputi penyusunan acara, pembuatan materi penyuluhan, pembuatan laporan dan video dokumentasi kegiatan PKM, dan pembuatan materi untuk mengevaluasi keberhasilan kegiatan penyuluhan.

Tahap selanjutnya adalah tahap pelaksanaan penyuluhan secara daring. Penyuluhan dilaksanakan secara daring dengan menggunakan aplikasi Zoom Meeting. Para peternak peserta penyuluhan sebelumnya telah diinformasikan mengenai teknis penyuluhan dengan menggunakan aplikasi Zoom Meeting, sehingga telah siap secara teknis. Penyuluhan dilaksanakan dengan sesi pemaparan materi mengenai teknologi limbah peternakan dan introduksi potensi tanaman rumput Mulato II sebagai hijauan untuk ruminansia. Setelah sesi pemaparan dilaksanakan, acara dilanjutkan dengan sesi diskusi. Setelah sesi diskusi berakhir, berakhir pula kegiatan penyuluhan ini. Meskipun begitu, para peserta penyuluhan diberikan kuesioner sebelum acara penyuluhan berakhir, dengan tujuan untuk mengetahui komentar para peserta terhadap jalannya acara penyuluhan. Selain itu, kuesioner ini dimaksudkan untuk mengukur apakah para peserta dapat menerima materi penyuluhan dengan baik, sehingga dapat diambil kesimpulan apakah kegiatan penyuluhan telah berjalan dengan sukses.

Tahap selanjutnya merupakan tahap evaluasi dan pendampingan peternak sebagai lanjutan dari rangkaian kegiatan pengabdian kepada masyarakat ini. Pada tahap evaluasi,

dilakukan rekapitulasi berdasarkan hasil pengisian (jawaban) dari para peserta di dalam kuesioner yang diberikan setelah tahap penyuluhan. Pendampingan peternak setelah penyuluhan tetap dilakukan secara online melalui grup Whatsapp. Pendampingan dilakukan selama 2 bulan menggunakan grup Whatsapp dan kunjungan ke peternak di KSU Tandangsari. Para mitra yang menjadi peserta penyuluhan bisa berkonsultasi lebih lanjut khususnya mengenai teknologi pengolahan limbah peternakan dan budidaya rumput mulato.

\section{HASIL DAN PEMBAHASAN}

\section{Tahap Persiapan}

Tahap ini dilaksanakan dengan tujuan untuk mempersiapkan segala hal yang diperlukan untuk kesuksesan pelaksanaan kegiatan penyuluhan secara daring. Hal pertama yang dipersiapkan adalah pemetaan calon mitra yang memiliki potensi untuk menjadi peserta penyuluhan. Para mahasiswa yang bergabung ke dalam tim pelaksana PPM virtual tersebar di berbagai daerah di Jawa Barat. Oleh karenanya, pemetaan dilaksanakan diberbagai daerah yang dekat dengan tempat anggota tim mahasiswa berada. Berdasarkan hasil proses pemetaan yang telah dikonsolidasikan oleh tim pelaksana PPM, maka diperoleh beberapa kelompok peternak yang berhasil dipetakan untuk menjadi peserta kegiatan penyuluhan, yang ditampilkan pada Tabel 1 .

Setelah para kelompok ternak yang potensial untuk mengikuti kegiatan penyuluhan ini berhasil dipetakan, Langkah selanjutnya adalah mewawancarai berbagai kelompok ternak tersebut, dengan tujuan untuk mengetahui permasalahan yang dominan terjadi di dalam peternakannya. Wawancara dilakukan oleh para anggota tim mahasiswa dengan menggunakan kuesioner yang telah dipersiapkan sebelumnya. Proses wawancara dilaksanakan secara daring melalui Whatsapp dan secara luring tanpa membentuk perkumpulan, dengan berpedoman kepada protokol kesehatan antisipasi penyebaran Covid-19 yang ketat.

Tabel 1. Pemetaan kelompok peternak yang terlibat dalam kegiatan pengabdian kepada masyarakat ini

\begin{tabular}{|c|c|c|c|}
\hline Kelompok Peternak & Kecamatan & $\begin{array}{c}\text { Kota/ } \\
\text { Kabupaten }\end{array}$ & Provinsi \\
\hline $\begin{array}{l}\text { Tunas Mekar, Subur } \\
\text { Makmur, Lembusari I, } \\
\text { Putra Saluyu, Rukun, } \\
\text { Wargi Saluyu, Bangkit } \\
\text { Jaya, Mekarasih, } \\
\text { berafiliasi dengan } \\
\text { KSU Tandangsari }\end{array}$ & Tanjungsari & Sumedang & $\begin{array}{l}\text { Jawa } \\
\text { Barat }\end{array}$ \\
\hline $\begin{array}{l}\text { Kelompok Tani } \\
\text { Tenjoayu, Kp. Cilayur } \\
\text { RT 01 / RW 01 Desa } \\
\text { Tenjoayu }\end{array}$ & Cicurug & Sukabumi & $\begin{array}{l}\text { Jawa } \\
\text { Barat }\end{array}$ \\
\hline $\begin{array}{l}\text { Peternakan Putra } \\
\text { Nusa, Desa Nusawiru, } \\
\text { Kondangjajar RT.23/ } \\
\text { RW.05 }\end{array}$ & Cijulang & Pangandaran & $\begin{array}{l}\text { Jawa } \\
\text { Barat }\end{array}$ \\
\hline $\begin{array}{l}\text { KDI Banyuresmi, pd } \\
\text { Gembala, Peternak } \\
\text { Bebedahan, }\end{array}$ & $\begin{array}{l}\text { Wanaraja } \\
\text { dan } \\
\text { Cikajang }\end{array}$ & Garut & $\begin{array}{l}\text { Jawa } \\
\text { Barat }\end{array}$ \\
\hline $\begin{array}{l}\text { Peternakan Sentra } \\
\text { Sapi Potong }\end{array}$ & $\begin{array}{l}\text { Tenayan } \\
\text { Raya }\end{array}$ & Pekanbaru & Riau \\
\hline
\end{tabular}

Berdasarkan hasil wawancara kepada para perwakilan kelompok peternak, diperoleh beberapa permasalahan yang terjadi di kelompok peternak, yakni permasalahan dalam pengadaan hijauan pakan yang berkualitas dan berkelanjutan, masalah kesehatan ternak, dan masalah terkait pengolahan limbah peternakan (Gambar 1). Berdasarkan permasalahan tersebut, dirumuskanlah solusi untuk menanganinya, yaitu dengan memutuskan untuk melaksanakan penyuluhan dengan judul "Pemberdayaan Kelompok Peternak Sapi melalui Introduksi Teknologi Pengolahan Limbah Peternakan dan Rumput Mulato sebagai Sumber Hijauan Ruminansia”.

Pada tahap selanjutnya, dilaksanakanlah persiapan yang lebih lanjut dengan fokus teknis acara 
penyuluhan. Sehingga, rapat-rapat yang dilaksanakan berfokus mendiskusikan tanggal pelaksanaan, cara pelaksanaan, narasumber penyuluhan, dan materi yang perlu dipersiapkan dalam acara penyuluhan daring (Gambar 2). Setelah melaksanakan beberapa kali rapat tim pelaksana PKM secara daring, maka diputuskanlah bahwa pelaksanaan kegiatan penyuluhan dilaksanakan secara daring dengan mengundang tiga narasumber yang dirasa memiliki kompetensi untuk memaparkan materi mengenai teknologi pengolahan limbah peternakan dan pengenalan rumput untuk dijadikan hijauan bagi ternak ruminansia.

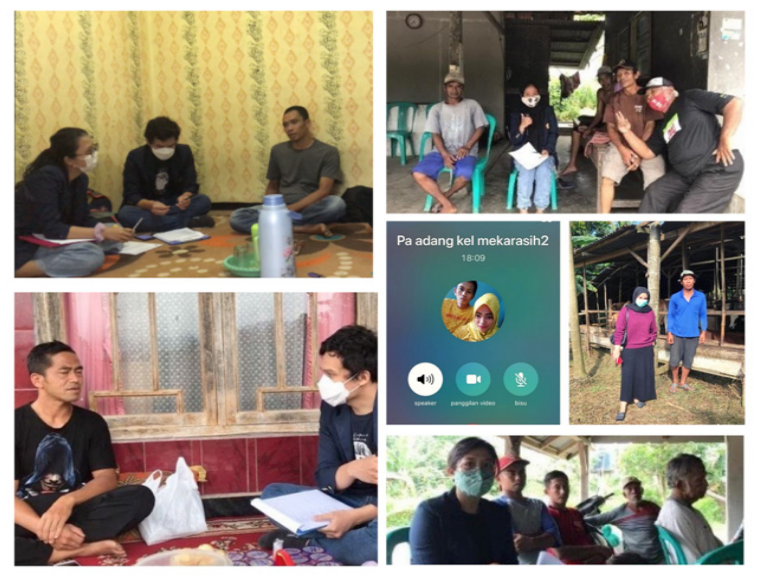

Gambar 1. Kolase dokumentasi proses wawancara dan pemetaan kelompok ternak baik secara daring maupun luring.
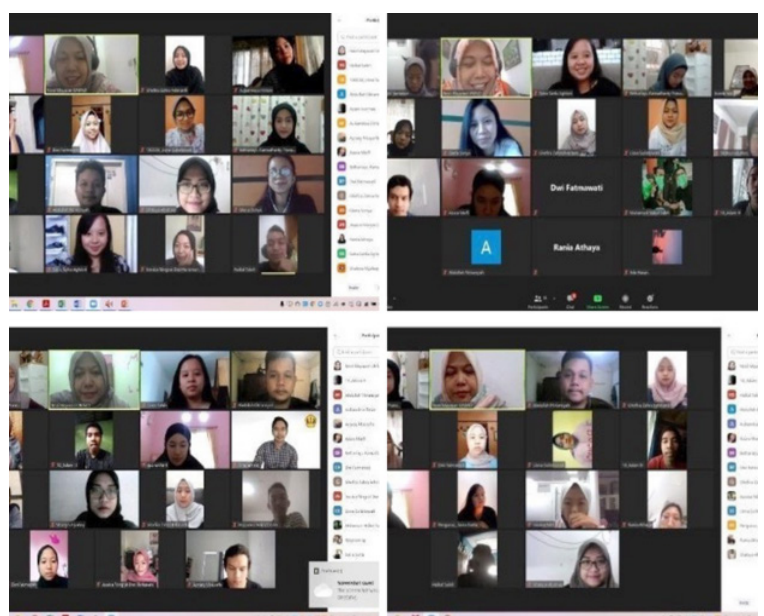

Gambar 2. Kolase dokumentasi kegiatan rapat persiapan pelaksanaan pengabdian kepada masyarakat secara daring.

\section{Tahap Pelaksanaan Penyuluhan Daring}

Penyuluhan secara daring dilaksanakan dengan aplikasi Zoom Meeting. Para peternak yang dirasa memiliki kesulitan secara teknis dan infrastruktur didampingi oleh anggota tim PKM mahasiswa yang juga berperan sebagai liaison officer (LO). Oleh karenanya, masalah teknis seperti jaringan dan sinyal internet sebagai pendukung utama pelaksanaan kegiatan penyuluhan secara daring dapat diantisipasi.
Penyampaian materi hingga diskusi telah dilakukan dan berjalan dengan lancar. Para mitra terlihat antusias dan semangat ketika diadakan kegiatan penyuluhan secara daring yang dilaksanakan via Zoom Meeting, dan menyimak secara seksama penjelasan yang disampaikan oleh pemateri. Materi yang disampaikan oleh tim pelaksana PKM sebagai narasumber meliputi pengenalan berbagai pilihan teknologi pengolahan limbah peternakan yang mungkin dapat diterapkan di peternakan yang dimiliki oleh kelompok peternak dan materi mengenai pengenalan tanaman rumput Mulato II yang memiliki berbagai keunggulan secara kandungan nutrien dan adaptabilitas yang baik dalam pembudidayaannya (Argel et al., 2007; Pizarro et al., 2013).

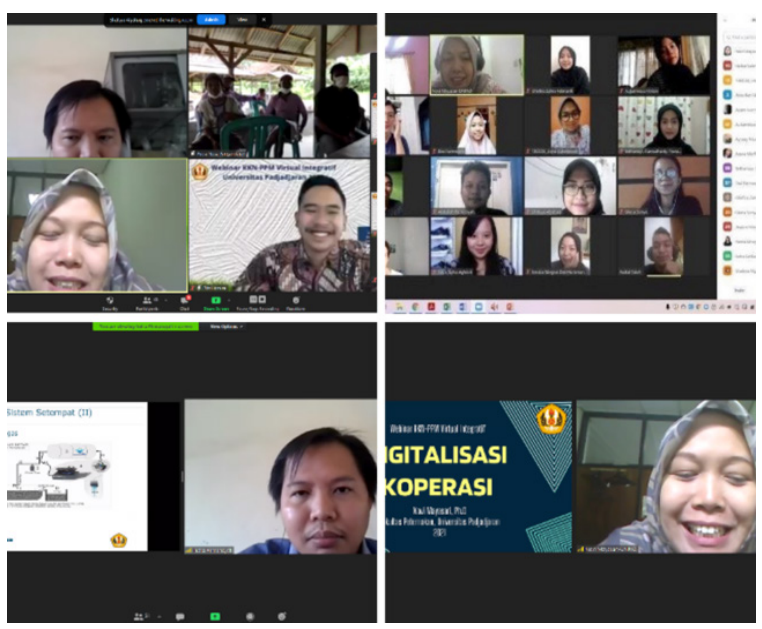

Gambar 3. Kolase dokumentasi pelaksanaan kegiatan penyuluhan secara daring.

Para peserta kegiatan penyuluhan daring aktif bertanya pada saat sesi diskusi penyuluhan dan sangat interaktif dengan para narasumber. Terdapat 50 orang yang tergabung dalam Zoom Meeting. Peternak banyak berdiskusi mengenai teknologi pengolahan limbah dan aplikasinya, potensi dari rumput mulato dan proses budidayanya, serta pemberiannya kepada ternak. Pada akhir penyampaian materi kemudian yang dilakukan diskusi untuk melakukan evaluasi untuk peternak.

\section{Tahap Evaluasi dan Pendampingan}

Kegiatan penyuluhan secara daring ini diakhiri dengan sesi evaluasi (post-test) dan pendampingan melalui luring dan daring. Tingkat keberhasilan pelaksanaan penyuluhan (kognitif) dilihat dari diskusi dalam kemampuan menjawab setelah penyuluhan berakhir. Pengetahuan peserta tentang potensi rumput mulato sebagai hijauan pakan sapi meningkat $90 \%$ dari sebelumnya. Sebagian besar (90\%) peserta dapat menjawab pertanyaan-pertanyaan yang diajukan oleh narasumber yang berkaitan dengan materi penyuluhan yang telah disampaikan sebagai bentuk evaluasi pemahamannya. 
Sebelum mengikuti penyuluhan, sebagian besar $90 \%$ peserta belum tahu mengenai rumput mulato. Hanya peternak dari KSU Tandangsari (5 orang; $10 \%$ ) mengetahui rumput mulato karena pada tahun sebelumnya telah mendapatkan hibah bibit rumput mulato. Peternak sebelum penyuluhan telah mengetahui beberapa teknologi pengolahan limbah seperti biogas dan composting ( $25 \%$ dari peserta). Setelah penyuluhan peternak mengenal teknologi pengolahan limbah lainnya seperti contructive wet land, vermicomposting, dan bioarang meningkat $80 \%$ dari sebelum penyuluhan.

Tabel 2. Hasil evaluasi pemahaman peserta dalam beberapa indikator materi penyuluhan

\begin{tabular}{|c|c|c|c|}
\hline & & Baseline & Pencapaian \\
\hline No & Indikator & $\begin{array}{c}\text { Sebelum } \\
\text { Kegiatan } \\
\text { Penyuluhan }\end{array}$ & $\begin{array}{c}\text { Setelah Kegiatan } \\
\text { Penyuluhan }\end{array}$ \\
\hline 1 & $\begin{array}{l}\text { Pengetahuan tentang } \\
\text { rumput mulato }\end{array}$ & $\begin{array}{l}\text { Sedikit tahu } \\
(10 \% \text { dari } \\
\text { peserta })\end{array}$ & $\begin{array}{l}\text { Meningkat } 80 \% \\
\text { dari peserta }\end{array}$ \\
\hline 2 & $\begin{array}{l}\text { Pengetahuan } \\
\text { peternak mengenai } \\
\text { potensi rumput } \\
\text { mulato }\end{array}$ & $\begin{array}{l}\text { Sedikit tahu } \\
(10 \% \text { dari } \\
\text { peserta) }\end{array}$ & $\begin{array}{l}\text { Meningkat } 80 \% \\
\text { dari peserta }\end{array}$ \\
\hline 3 & $\begin{array}{l}\text { Pengetahuan } \\
\text { peternak mengenai } \\
\text { budidaya rumput } \\
\text { mulato }\end{array}$ & $\begin{array}{l}\text { Sedikit tahu } \\
(10 \% \text { dari } \\
\text { peserta) }\end{array}$ & $\begin{array}{l}\text { Meningkat } 80 \% \\
\text { dari peserta }\end{array}$ \\
\hline 4 & $\begin{array}{l}\text { Pengetahuan } \\
\text { peternak mengenai } \\
\text { jenis teknologi } \\
\text { pengolahan limbah }\end{array}$ & $\begin{array}{l}\text { Sedikit tahu } \\
(25 \% \text { dari } \\
\text { peserta) }\end{array}$ & $\begin{array}{l}\text { Meningkat } 50 \% \\
\text { dari peserta }\end{array}$ \\
\hline
\end{tabular}

Indikator keberhasilan penyuluhan selain dari post-test saat diskusi, indikator utama adalah keberhasilan peternak membudidayakan rumput mulato hingga mendapatkan anakan baru, mengaplikasikan teknologi pengolahan limbah yang sesuai dengan kemampuan peternak masingmasing serta kesungguhan dan hasil yang diperoleh. Pendampingan dilakukan satu bulan setelah dilakukan dengan kunjungan ke peternak di KSU. Beberapa peternak telah mengaplikasikan biogas dan contructive wet land. Kegiatan ini dapat terlaksana dengan baik karena terdapat beberapa faktor pendukung, meskipun juga memiliki beberapa faktor penghambat yang diperlukan langkah-langkah lanjutan. Faktor pendukung dan penghambat tersebut yaitu:

\section{Faktor pendukung keberhasilan kegiatan:}

1. Produksi susu yang dihasilkan sudah jelas pemasarannya sehingga tidak ada kesulitan dalam penjualan susu.

2. Antusiasme dan partisipasi petani peternak sangat baik didukung oleh kesediaan pengurus koperasi dan pihak akademisi.
3. Kegiatan ini merupakan kelanjutan dari kegiatan pengabdian rutin yang dilakukan di kelompok Tunas Mekar dan Putra Nusa dari tahun 2018 hingga sekarang. Kegiatan ini mendapat dukungan penuh dari petani peternak, dan masyarakat.

4. Kegiatan ini mendapat dukungan dana yang memadai dan lancar dari DRPMI UNPAD

\section{Faktor yang menjadi penghambat:}

1. Penyediaan baik Benih/biji ataupun bibit rumput Mulato hybrid II masih terbatas

2. Kurangnya lahan dan permodalan untuk mendukung program hijauan dan berkualitas serta untuk mengolah limah peternakan

3. Regenerasi peternak yang tidak berjalan lancar karena kurang minatnya generasi muda akan bidang

\section{SIMPULAN}

Rangkaian kegiatan pengabdian kepada masyarakat secara daring kepada beberapa kelompok peternak yang tersebar di Jawa Barat dan Riau telah terlaksana sesuai dengan harapan dan tujuan, dengan dukungan berbagai pihak termasuk para mahasiswa Kuliah Kerja Nyata (KKN) yang bergabung ke dalam tim pelaksana PKM. Kegiatan penyuluhan daring yang berisikan materi mengenai pengenalan teknologi pengolahan limbah peternakan dan pengenalan potensi rumput mulato sebagai hijauan untuk ruminansia dapat diterima dengan baik oleh para peserta penyuluhan, ditandai dengan antusiasme peserta dan hampir 90\% peserta dapat menjawab pertanyaan evaluasi dari para narasumber. Program lanjutan dari program PKM ini adalah kegiatan pengenalan teknologi pengawetan rumput mulato sehingga peternak memiliki tabungan hijauan yang berkualitas.

\section{UCAPAN TERIMA KASIH}

Ucapan terima kasih disampaikan oleh penulis kepada DRPMI Universitas Padjadjaran yang telah membiayai kegiatan PPM virtual ini. Ucapan terima kasih juga disampaikan kepada Ketua Koperasi KSU Tandangsari Kab. Sumedang, Ketua Kelompok Petani Tenjoayu Kab. Sukabumi, Ketua Kelompok Peternak Putra Nusa Kab. Pangandaran, dan Ketua Kelompok Peternak Banyuresmi Kab. Garut, dan Ketua Kelompok Peternakan Sentra Sapi Potong, Kab. Pekanbaru, Provinsi Riau. Penulis juga mengucapkan terima kasih kepada para mahasiswa Kuliah Kerja Nyata (KKN) 2021 Integratif yang telah mendukung kesuksesan kegiatan penyuluhan ini. 


\section{DAFTAR PUSTAKA}

Adawiah, Sutardi, T., Toharmat, T., Manalu, W., \& Nahrowi. 2006. Responses of milk quality to roasted soybeans, calcium soap and organic mineral supplementation in dairy cattle diets. Jurnal Ilmu Ternak Dan Veteriner; Vol 11, No 4 (2006): 2006, 11(4). http://medpub. litbang.pertanian.go.id/index.php/jitv/article/ view/538/547

Argel, P. J., Miles, J. W., Guiot, J. D., Cuadrado, H., \& Lascano, C. E. 2007. Cultivar Mulato II (Brachiaria hybrid CIAT 36087): A highquality forage grass, resistant to spittlebugs and adapted to well-drained, acid tropical soils. The International Center for Tropical Agriculture (CIAT). http://ciat-library.ciat. cgiar.org/Articulos_Ciat/mulato_ii_ingles.pdf

Badan Pusat Statistik Republik Indonesia. 2020. Populasi Ternak. In Peternakan dalam Angka (May 2020). BPS-RI.

Budde, J., Prochnow, A., Plöchl, M., Suárez Quiñones, T., \& Heiermann, M. 2016. Energy balance, greenhouse gas emissions, and profitability of thermobarical pretreatment of cattle waste in anaerobic digestion. Waste Management, 49, 390-410. https://doi. org/10.1016/j.wasman.2015.12.003

Grabber, J. H. 2005. How Do Lignin Composition, Structure, and Cross-Linking Affect Degradability? A Review of Cell Wall Model Studies. Crop Science, 45(3), 820-831. https:// doi.org/10.2135/cropsci2004.0191

Inyang, U., Vendramini, J. M. B., Sollenberger, L. E., Sellers, B., Adesogan, A., Paiva, L., \& Lunpha, A. 2010. Forage Species and Stocking Rate Effects on Animal Performance and Herbage Responses of 'Mulato' and Bahiagrass Pastures. Crop Science, 50(3), 1079-1085. https://doi.org/10.2135/cropsci2009.05.0267

Kaufmann, T. 2015. Sustainable livestock production: Low emission farm - The innovative combination of nutrient, emission and waste management with special emphasis on Chinese pig production. Animal Nutrition, 1(3), 104-112. https://doi.org/10.1016/j. aninu.2015.08.001

Koneswaran, G., \& Nierenberg, D. 2008. Global Farm Animal Production and Global
Warming: Impacting and Mitigating Climate Change. Environmental Health Perspectives, 116(5), 578-582. https://doi.org/10.1289/ ehp.11034

Maass, B. L., Midega, C. A. O., Mutimura, M., Rahetlah, V. B., Salgado, P., Kabirizi, J. M., Khan, Z. R., Ghimire, S. R., \& Rao, I. M. 2015. Homecoming of Brachiaria: Improved Hybrids Prove Useful for African Animal Agriculture. East African Agricultural and Forestry Journal, 81(1), 71-78. https://doi.or g/10.1080/00128325.2015.1041263

Mayasari, N., \& Ismiraj, M. R. 2019. Introduksi Pemanfaatan Legum Indigofera zollingeriana sebagai Pengganti Sebagian Konsentrat pada SapiPotong di KelompokPeternakPutraNusa, Desa Kondangdjaja, Kecamatan Cijulang, Kabupaten Pangandaran. Dharmakarya, 8(2), 105-110. doi: http://dx.doi.org/10.24198/ dharmakarya.v8i2.21055

Mayasari, N., Salman, L. B., Setyowati, E. Y., \& Ismiraj, M. R. 2018. Pembuatan Ransum Komplit dengan Pemanfaatan Indigofera zollingeriana dan Mineral Anorganik: Peningkatan Kesehatan dan Produktivitas Sapi Perah pada Kelompok Ternak Sapi Perah KSU Tandangsari, Kecamatan Tanjungsari, Kabupaten Sumedang. Jurnal Pengabdian Kepada Masyarakat, 2(4), 375-378.

Pizarro, E. A., Hare, M. D., Mutimura, M., \& Changjun, B. 2013. Brachiaria hybrids: Potential, forage use and seed yield. Tropical Grasslands-Forrajes Tropicales, 1(1), 31-35.

Sorathiya,L.M.,Fulsoundar,A.B., Tyagi,K.K.,Patel, M. D., \& Singh, R. R. 2014. Eco-friendly and modern methods of livestock waste recycling for enhancing farm profitability. International Journal of Recycling of Organic Waste in Agriculture, 3(1), 50. https://doi.org/10.1007/ s40093-014-0050-6

Widyobroto, W. P., Rochijan, R., Ismaya, I., Adiarto, A., \& Suranindyah, Y. Y. 2016. The Impact of Balanced Energy and Protein Supplementation to Milk Production and Quality in Early Lactating Dairy Cows. Journal of the Indonesian Tropical Animal Agriculture, 41(2), 83-90. https://doi. org/10.14710/jitaa.41.2.83-90 